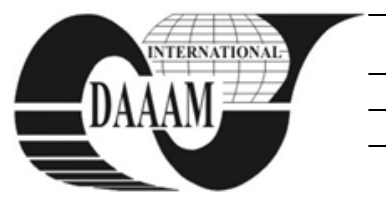

Annals of DAAAM for 2011 \& Proceedings of the 22nd International DAAAM Symposium, Volume 22, No. 1, ISSN 1726-9679 ISBN 978-3-901509-83-4, Editor B. Katalinic, Published by DAAAM International, Vienna, Austria, EU, 2011 Make Harmony between Technology and Nature, and Your Mind will Fly Free as a Bird Annals \& Proceedings of DAAAM International 2011

\title{
MECHANIZATION AND WELDING CONTROL STRUCTURE METAL SEAT AUTO
}

\author{
SAPARIUC, F[lorin] - A[lexandru]; UNCU, I[onut]; DRAGAN, A[drian] M[arian]; HANEA RADU, C[amelia] \\ M[aria]; BANEA, A[lexandru] \& TRIF, I[acob] N[icolae]
}

\begin{abstract}
The paper presents the fabrication technology for metal structure of automobile seats. Applied technology for type backrest metal frame is welding points with specifying the parameters for welding and the working equipment in this direction there are used mechanized devices for attaching the frame and caps with sensors which validate the points of weld in the correct positions. This system removes the execution of waste products in the process of welding and validates a correctly welding process.

Key words: manufacturing technology, welding points, devices
\end{abstract}

\section{INTRODUCTION}

The seats are important components in the construction of the insides of a passenger car. Their production requires a strong metal structure, a specific design and a rigorously designed fabrication technologies.

Front and rear seats of passenger cars have a metal construction of backrest made in three variants of sizes: 40, RSB 60,100 presented in Figure 1.

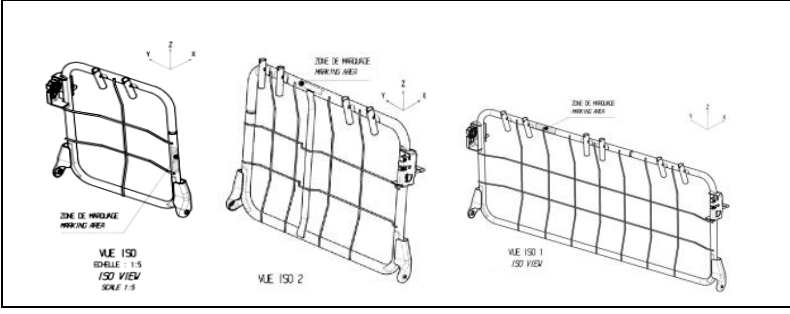

Fig. 1. Seats backrest variants. Joni, N.2005

Backrest construction consist of a metal frame made of steel pipe on that are welded hinge clamps, strengthening bars and a metal netting on which it is applied subsequently upholstery furniture.

Backrest construction consists of a metal frame made of pipe that are welded hinge clamps, bars and wire mesh reinforcement which is then applied to upholstery.

\section{MANUFACTURING TECHNOLOGY}

Manufacturing of backrest reinforcement is made in welded construction through pressure points. In this sense it is use an auxiliary fixing device with pneumatic drive Figure 2.

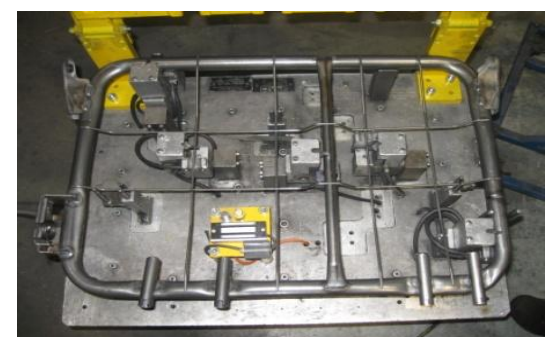

Fig. 2. Auxiliary fastening device
Performed operations are:

- preassembled backrest is placed within the device,

positioned on the settlement prisms.

- Fix pneumatic the central breech.

- the wire netting is place on positioning dampeners.

- the wire netting is pneumatic fixed with locks placed on sides.

- the locking lid is coming down.

- run the welding of wire netting frame, as defined in the instructions for welding sequence.

- the device spins as necessary. Iovanas R,2005.

The equipment used for the welding points is Lincoln CV400. Welding parameters are presented in Table 1:

\begin{tabular}{|l|l|l|l|}
\hline $\begin{array}{l}\text { Wire } \\
\text { Type: }\end{array}$ & $\begin{array}{l}\text { G3Si1(G-46)- } \\
\text { EN 440 }\end{array}$ & $\begin{array}{l}\text { Welding } \\
\text { current } \\
\text { intensity }\end{array}$ & $110-120 \mathrm{~A}$ \\
\hline $\begin{array}{l}\text { Wire } \\
\text { diameter: }\end{array}$ & $1 \mathrm{~mm}$ & $\begin{array}{l}\text { Advance } \\
\text { wire speed: }\end{array}$ & $\begin{array}{l}5,5-6,0 \\
\mathrm{~m} / \mathrm{min}\end{array}$ \\
\hline $\begin{array}{l}\text { Protective } \\
\text { gas arc: }\end{array}$ & $\begin{array}{l}\mathrm{C} 1-\mathrm{EN} 439 \\
100 \% \mathrm{CO}_{2}\end{array}$ & $\begin{array}{l}\text { The voltage } \\
\text { at the power } \\
\text { supplies. }\end{array}$ & $\begin{array}{l}19,0-21,0 \mathrm{~V} * / \\
\text { tr.B3-B4**/ } \\
\text { tr.24-26*** }\end{array}$ \\
\hline Gas flow: & $11-131 / \mathrm{min}$ & $\begin{array}{l}\text { Withdrawal } \\
\text { from the gas } \\
\text { nozzle } \\
\text { contact. }\end{array}$ & $0 \ldots 5 \mathrm{~mm}$ \\
\hline $\begin{array}{l}\text { Welding } \\
\text { position: }\end{array}$ & $\begin{array}{l}\text { Horizontal, } \\
\text { vertical } \\
\text { descendant, } \\
\text { upside down. }\end{array}$ & $\begin{array}{l}\text { Number of } \\
\text { passes: }\end{array}$ & 1 \\
\hline Polarity: & $\begin{array}{l}\text { CC+ (plus the } \\
\text { torch) }\end{array}$ & oscillation: & Without \\
\hline $\begin{array}{l}\text { Free } \\
\text { length of } \\
\text { wire: }\end{array}$ & $12 \ldots 14$ mm & & \\
\hline
\end{tabular}

Tab. 1. Welding parameters

After completion of the number of points the metal cover is automatically unlocked. Then run the following operations:

- opens the metal lid in vertical position.

- check visually the presence of the 14 weld points and verify if their position is on the axis of the tube

- check visually the presence and the appearance of the 18 welding cords on the front face of the reinforcement.

- remove the piece from the device and check visually the presence and the appearance of the 6 welding cords on the back of the reinforcement

- check visually the presence of the mark on the lower right bracket. The text must be clearly marked

- placed the assembly on the intended support.

On the car backrest are welded by pressure points two clamping flanges, left, right, Figure 3. 


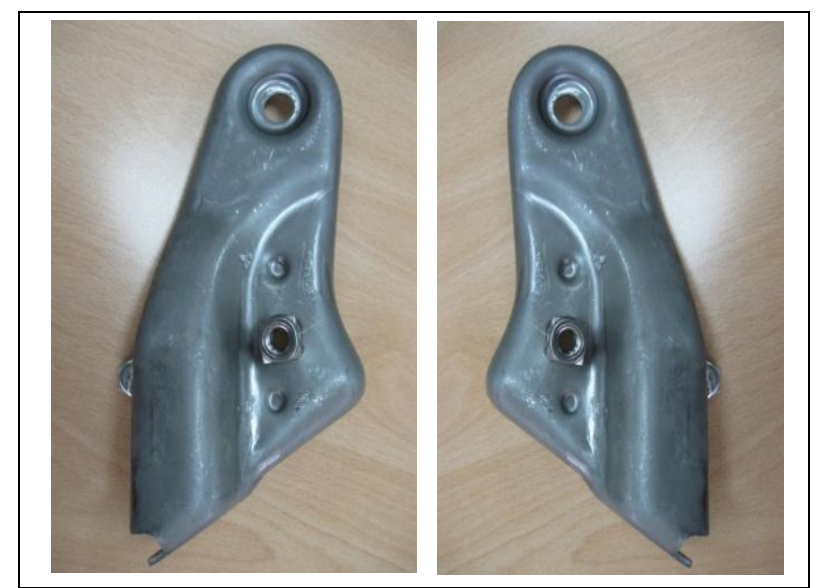

Fig. 3. Flange backrest, left, right

The welding parameters for the two flanges are presented in table 2:

\begin{tabular}{|l|l|l|}
\hline Time for pre- tightening & $1 / 50 \mathrm{sec}$. & 35 \\
\hline Time tightening & $1 / 50 \mathrm{sec}$. & 45 \\
\hline Welding Current & $\mathrm{kA}$ & 23 \\
\hline Welding time & $1 / 50 \mathrm{sec}$. & 10 \\
\hline Hold time & $1 / 50 \mathrm{sec}$. & 30 \\
\hline Pressure Welding & bari & 6,5 \\
\hline Welding Power & daN & 1500 \\
\hline
\end{tabular}

Tab. 2. Welding parameters from the two flanges

\section{CONTROL OF WELDED CONSTRUCTION}

The control system of the welded structure of the wire netting on the backrest frame is composed of: presence sensors for the piece in the fixture, a control device for the pneumatic fixture, connection cables, signalling lamp, counter for counting of welded points by pressure. If the amount of points welded are not validated and the piece is removed from device, green lamp turns off and the red lamp will stay on constantly. The system is locked and display shows " piece unfinished ".In Figure 4 is presented the control system and validation of welding points. .I.Uncu 2011.

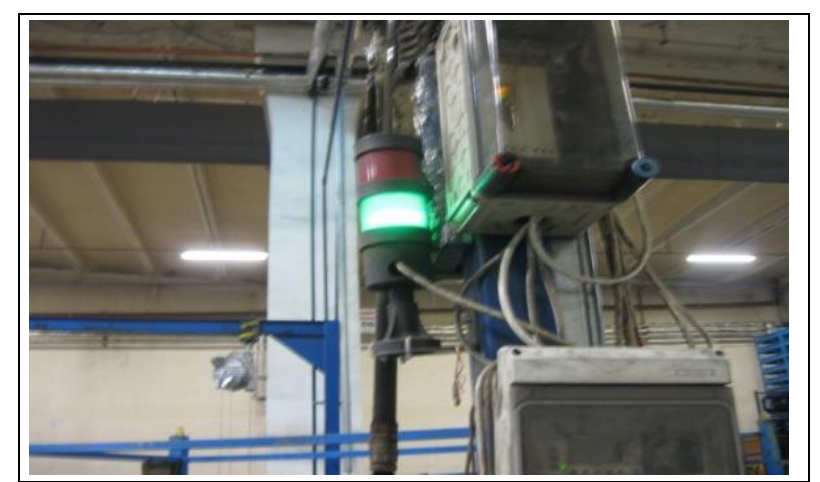

Fig. 4. Control lamp for welding process

To achieve this control system will be implemented additional devices (caps), that will ensure the welding of the wire netting on the tube of seat backrest

They will have the following functions:

Allow a movement of rotating-tipping between two positions - top position (100 degrees from horizontal) to represent the position in which the operator load pieces for in the device and a horizontal position (lid closed) to represent the position the the welder will perform welding operations;
Raising the " caps " to the vertical position will be assisted by two sensors (gas pistons), calculated so as to ensure the removal and not to oppose a excessive force excessive at the descent of the cover, the maximum force shall be established in due time;

Newly installed devices (caps) will contain a number of sensors equal to the number of spot welds made in the device, sensors that allows the detection of the upper clamp electrode performance throughout for each spot welds. All sensors will be provided with mechanical protection elements in order to avoid possible deterioration by contact with welding tongs or accidentally hitting. Sensors will be connected to a connecting element "central" installed on the cap, which will allow for increased reliability reducing the number of threas of connection between sensors and machine station; the design of electrical connections must take into account the movements of rotation of device and provide protection to ensure the mechanical and electrical integrity of wires during manipulation;

Covers will be provided with a closing / locking device in the welding position (horizontal) position which will be checked by means of a sensor connected to the PLC station, covers can be opened only upon the successful completion of all welds intended for operation;

Lids are provided with "windows" to avoid the interference with metal fittings, wire mesh and structural elements of the welding device, caps will be provided with guiding points to ensure an correct welding position for all welds specified in the job.

\section{CONCLUSION}

Making the car seats in welded construction require a performant technology and modern equipment.

Setting the parameters of the welding points technology, the material used and the condition wich are essential for the development of quality of finished products.

Adjustment of mechanization auxiliary devices and controlvalidation systems leading to the elimination scraps, and savings of labor and material.

\section{ACKNOWLEDGEMENT}

„ACKNOWLEDGEMENT: This paper is supported by the Sectoral Operational Programme Human Resources Development (SOP HRD), ID76945 financed from the European Social Fund and by the Romanian Government.

\section{REFERENCES}

Georgescu, V., Mircea, O., et al.: Sudarea prin presiune. Metode clasice (Pressure welding. Classical Methods). Brasov. Lux Libris Publishing House, 2002

Joni, N. Trif, I. N.: Sudarea robotizata cu arc electric (Robotic arc welding). Brasov. Lux Libris Publishing House, 2005

Standard ISO 14270:2000 specimen, dimension and procedures for mechanized peel testing resistance spot, seam and embossed projection welds

I.Uncu, S. Gansca, F. Sapariuc, N. Trif, A new system for controlling the car seats welding points, Bulletin of the Transilvania University of Brasov Vol 3(52)-2011 Series I: Engineering Sciences

Iovanas R., Sudarea electrica prin presiune, Editura Sudura, Timisoara, 2005 